\title{
PENGARUH CAR (CAR) DAN NON PERFORMING LOAN (NPL) TERHADAP KINERJA KEUANGAN BANK UMUM KONVENSIONAL PERIODE 2013 - 2015
}

\author{
Ati Sumiati \\ Ekky Karmila \\ Universitas Negeri Jakarta
}

\begin{abstract}
ABSTRAK
Penelitian ini bertujuan untuk mengetahui pengaruh CAR(CAR) dan Non-Performing Loan (NPL) terhadap Kinerja Keuangan Bank Umum Konvensional Periode 2013 - 2015. Penelitian ini menggunakan teknik non-probability sampling dan metode purposive sampling. Pengumpulan data menggunakan data sekunder, yaitu dengan mengambil data dari laporan tahunan masing-masing website bank umum konvensional. Populasi terjangkau dalam penelitian ini adalah Bank Umum Konvensional yang berjumlah 43 bank dengan sampel 39 bank. Teknik analisis data yang digunakan adalah uji normalitas, uji asumsi klasik, dan uji hipotesis. Berdasarkan hasil analisis data diketahui bahwa ada pengaruh positif antara CAR(CAR) dengan Kinerja Keuangan, sedangkan non-performing loan berpengaruh negatif terhadap Kinerja Keuangan. Secara simultan terdapat pengaruh antara CARdan NonPerforming Loan terhadap Kinerja Keuangan.
\end{abstract}

Kata Kunci: Capital Adequacy Ratio (CAR), Non-Performing Loan (NPL), Kinerja Keuangan

\section{PENDAHULUAN}

Perbankan merupakan salah satu sekto terpenting dalam perekonomian negara. Bank dianggap sebagai roda penggerak perekonomian karena bank merupakan sektor usaha yang mengatur perputaran uang masyarakat dan negara.

Menurut Peraturan Bank Indonesia Nomor: 6/10/PBI/2004 tentang Sistem Penilaian Tingkat Kesehatan, tingkat kesehatan bank mencakup penilaian terhadap rasio CAMEL. Namun setelah dikeluarkannya Peraturan Bank Indonesia Nomor 6/10/PI/2004 tanggal 12 April 2004 aspek penilaian kinerja perbankan bertambah satu aspek yakni sensitivity to market risk sehingga disingkat menjadi CAMELS. Penilaian kesehatan bank tersebut menggunakan rasio keuangan antara lain rasio permodalan (Capital), rasio kualiatas aset (Assets), kualitas manajemen (Management), rasio rentabilitas bank (Earning), rasio-rasio likuiditas bank (Liquidity), dan rasio untuk mengukur sensitivitas risiko pasar (Sensitivity to market risk). Hasil pengukuran berdasarkan rasio tersebut diterapkan untuk menentukan apakah bank dapat dikategorikan sehat, cukup sehat, kurang sehat, atau bahkan tidak sehat.

Adanya ketentuan tentang tingkat kesehatan yang menggambarkan kondisi keuangan bank merupakan kepentingan seluruh pihak yang terkait baik pemilik, pengelola (manajemen) bank, masyarakat pengguna jasa bank, Bank Indonesia selaku otoritas pengawasan bank, dan pihak lainnya. Hal ini dikarenakan 
informasi tersebut dapat digunakan oleh pihak-pihak tersebut untuk mengevaluasi kinerja bank dalam menerapkan prinsip kehati-hatian, kepatuhan terhadap ketentuan yang berlaku dan manajemen risiko.

Namun sama halnya dengan perusahaan non-bank, selain memfasilitasi masyarakat dan mendorong perekonomian, bank juga merupakan salah satu badan usaha yang mencari keuntungan atau laba. Manajemen bank selalu memperhatikan keuntungan banknya sebagaimana perusahaan lain non-bank, karena bank saling bersaing di pasar modal, dan persentase laba yang tinggi merupakan kunci untuk menarik minat calon investor.

Beberapa tahun terakhir sektor perbankan mulai melemah. Perekonomian yang tidak stabil membuat dunia perbankan turut terkena dampaknya secara langsung. Pertumbuhan laba menjadi lambat diikuti dengan persentase pertumbuhan yang sangat tipis setiap tahunnya.

Ada banyak faktor yang mempengaruhi lambatnya bahkan menurunnya pertumbuhan laba perbankan. Faktor pertama dan yang paling dominan terjadi adalah meningatknya kredit macet (non-performing loan). Adanya peningkatan kredit macet sangat berpengaruh terhadap laba yang diperoleh pada tahun berjalan. Besarnya pinjaman yang diberikan oleh bank memiliki Jurnal IImiah Wahana Akuntansi harapan yang besar pula untuk dapat dikembalikan sepenuhnya beserta bunga yang dibebankan. Namun sayangnya tidak semua kredit yang diberikan mampu berjalan dengan lancar.

Hal ini didukung dengan pernyataan yang disampaikan oleh Direktur Utama BNI Achmad Baiquni yang mengatakan penyebab utama dari penurunan laba secara persentase adalah karena tingkat kredit bermasalah (Non-Performing Loan) perseroan mengalami kenaikan.

Faktor kedua yang mempengaruhi pertumbuhan laba perbankan adalah pertumbuhan kredit yang lemah. Kredit merupakan sumber utama pendapatan bank. Melemahnya pertumbuhan kredit tentu akan mengakibatkan berkurangnya pendapatan dan pada akhirnya berdampak pada laba bersih yang dihasilkan.

Hal ini didukung oleh pernyataan Analis PT Mandiri Sekuritas, Tjandra Lienandjaja yang menyatakan perbankan membukukan pertumbuhan laba sebesar 5\% secara tahunan pada kuartal I/2015 karena pertumbuhan kredit yang lemah yaitu $10 \%$ secara tahunan.

Faktor ketiga yang mempengaruhi laba perbankan adalah menurunnya nilai selisih laba bersih/NIM (Net Interest Margin) yang diterima oleh bank. Bank merupakan perusahaan yang menyediakan pelayanan berupa jasa, di mana sebagian besar pendapatannya bersumber dari bunga. Bunga yang didapat merupakan hasil penyediaan jasa berupa kredit, 
tabungan, giro, deposito, dan simpanan berjangka. Sehingga, adanya penurunan selisih bunga bersih yang diterima akan berdampak pada pendapatan bank yang selanjutnya juga akan mempengaruhi besarnya laba yang diterima.

Didukung dengan pernyataan yang disampaikan oleh Junior Sub ManagerBanking System and Systematic Risk Analyst LPS Totong Sudarto bahwa laba perbankan yang mengalami penurunan terlihat dari rasio NIM yang juga ikut menurun. NIM mengalami penurunan drastis, sejak otoritas moNeter menjalankan kebijakan moNeter yang ketat pada 2013 dari rerata dikisaran 5,4\% menjadi 4,3\% di akhir tahun lalu.

Faktor keempat yang mempengaruhi pertumbuhan laba perbankan adalah besarnya rasio CAR yang dimiliki oleh bank. CAR merupakan rasio permodalan yang menunjukkan kemampuan bank dalam menyediakan dana untuk keperluan pengembangan usaha dan menampung kemungkinan resiko kerugian yang mungkin terjadi dalam kegiatan operasional bank. Besarnya CAR yang dimiliki oleh bank akan mempengaruhi kemampuan bank itu sendiri dalam menjalankan usahanya dan mempengaruhi besarnya pendapatan yang diterima.

Faktor kelima yang mempengaruhi pertumbuhan laba perbankan adalah meningkatnya rasio BOPO (Beban Operasional Pendapatan Operasional). BOPO merupakan rasio yang digunakan Jurnal Ilmiah Wahana Akuntansi untuk mengukur kemampuan manajemen bank dalam mengendalikan biaya operasional terhadap pendapatan operasional. Semakin kecil rasio ini menandakan bahwa semakin efisien biaya operasional yang dikeluarkan oleh bank sehingga berpengaruh terhadap laba yang akan diperoleh oleh bank.

\section{PERUMUSAN MASALAH}

Berdasarkan identifikasi dan pembatasan masalah di atas, maka dapat dirumuskan masalah yang ada, yaitu:

1. Adakah pengaruh antara CAR dengan kinerja keuangan?

2. Adakah pengaruh antara NPL dengan kinerja keuangan?

3. Adakah pengaruh CAR dan NPL secara bersama-sama dengan kinerja keuangan?

\section{KAJIAN PUSTAKA， KERANGKA TEORITIK, DAN HIPOTESIS}

\section{Definisi Kinerja Keuangan}

Irham (2012) menyatakan bahwa kinerja keuangan adalah suatu analisis yang dilakukan untuk melihat sejauh mana suatu perusahaan telah melaksanakan dengan menggunakan aturan-aturan pelaksanaan keuangan secara baik dan benar. Seperti dengan membuat suatu laporan keuangan yang telah memenuhi standar dan ketentuan dalam SAK (Standar Akuntansi Keuangan) atau 
GAAP (General Accepted Accounting Principle), dan lainnya.

Menurut Taswan (2006) tingkat kesehatan bank merupakan hasil penilaian kualitatif atas berbagai aspek yang berpengaruh terhadap kondisi atau kinerja keuangansuatu bank melalui penilaian faktor permodalan (capital), kualitas aset (assets), manajemen (management), rentabilitas (earning power), likuiditas (liquidity), dan sensitivitas terhadap risiko pasar (sensitivity to market risk) atau disingkat dengan istilah CAMELS.

Menurut Rimsky (2005) kinerja keuangan perbankan terlihat dari tingkat kesehatan bank yang berhubungan dengan status bank yang digolongkan memiliki kecukupan modal, kualitas aset, kualitas manajemen, likuiditas, rentabilitas, solvabilitas, dan aspek lain yang berhubungan dengan usaha bank, dan dalam melakukan kewajiban kegiatan usahanya sesuai dengan prinsip kehatihatian.

\section{Rumus Menghitung Kinerja Keuangan}

Menurut J. Fred Weston dalam Kasmir (2009) bentuk-bentuk rasio keuangan, yaitu: (1) rasio likuiditas; (2) rasio solvabilitas, (3) rasio aktivitas, (4) rasio profitabilitas; (5) rasio pertumbuhan; dan (6) rasio penilaian.

Dalam penelitian ini, indikator terhadap kinerja keuangan menggunakan rasio pertumbuhan laba. Menurut Harahap (2008) pertumbuhan laba adalah rasio Jurnal IImiah Wahana Akuntansi yang menunjukkan kemampuan perusahaan meningkatkan laba bersih dibandingkan tahun lalu. Adapun penghitungan rasio pertumbuhan laba sebagai berikut :

$$
\text { Yit }=\frac{Y i t-Y i t-1}{\text { Yit }-1}
$$

\section{Definisi CAR (Capital Adequacy Ratio)}

Dalam rangka penerapan prudential banking (prinsip kehati-hatian) dalam pengelolaan bank, Bank Indonesia (BI) telah memberikan batasan-batasan yang harus dilaksanakan oleh setiap bank yang melakukan kegiatan usaha perbankannya di Indonesia. Rasio kehati-hatian salah satunya adalah CAR dengan mencari persentase dari nilai perbandingan antara modal dan aktiva tertimbang menurut risiko (ATMR) (Riyadi, 2004).

Darmawi (2011) mengatakan bahwa CAR adalah rasio kecukupan modal minimal yang harus dimiliki oleh setiap bank umum berdasarkan ketetapan BI (Bank Indonesia) yaitu sebesar 8\%.

Menurut Hasibuan (2008) CAR adalah kebutuhan modal minimum bank yang dihitung berdasarkan ATMR (Aktiva Tertimbang Menurut Risiko). CAR (KPMM) yang didasarkan pada standar BIS (8\%) adalah salah satu cara untuk menghitung apakah modal yang ada pada suatu bank telah memadai atau belum memadai. 


\section{Rumus Menghitung CAR}

Dalam menentukan besarnya Modal Minimum bagi suatu bank dapat dilakukan beberapa tahap yaitu pertama meNetapkan Dasar Perhitungan Kebutuhan Modal dan kedua meNetapkan Bobot Risiko Aktiva yang terdapat pada Neraca bank serta Bobot Risiko Aktiva Administratif (Riyadi, 2004). Perhitungan kebutuhan modal didasarkan pada Aktiva Tertimbang Menurut Risiko (ATMR).

Proksi yang digunakan dalam penentuan CAR suatu bank adalah sebagai berikut:

\section{$\mathrm{CAR}=\frac{\text { Modal }}{\text { ATMR }} \times 100 \%$}

\section{Definisi NPL (Non-Performing Loan)}

Menurut Arthesa (2009)kredit macet adalah kredit yang sejak jatuh tempo tidak dapat dilunasi oleh debitur sebagaimana mestinya sesuai dengan perjanjian yang telah disepakati. Pengertian jatuh tempo tersebut sesuai dengan ketentuan kolektibilitas Bank Indonesia.

MacDonald (2009) berpendapat bahwa kredit macet adalah kredit/pinjaman yang telah lewat jatuh tempo lebih dari 90 hari. Dan juga kredit/pinjaman ditetapkan sebagai kredit macet (non-performing) ketika kredit ditempatkan pada status non-akrual atau ketika istilah secara substansial kredit diubah ke dalam status restrukturisasi. Non-akrual artinya bank tersebut Jurnal IImiah Wahana Akuntansi menghapus seluruh bunga pinjaman yang telah dicatat namun tidak tertagih.

Sedangkan Hasibuan (2008)
mengatakan bahwa kredit macet
merupakan kredit yang diklasifikasikan
pembayarannya tidak lancar yang
dilakukan oleh debitor bersangkutan.

Rumus Menghitung NPL

Menurut Riyadi (2004)NPL memiliki 2 jenis dengan perhitungan yang berbeda. Untuk NPL Gross dapat dihitung dengan cara melakukan perbandingan antara jumlah kredit yang diberikan dengan tingkat kolektibilitas 3 sampai dengan 5 (kategori kredit kurang lancar, diragukan, dan macet) terhadap total seluruh kredit yang diberikan oleh bank lalu dikalikan $100 \%$. Sedangkan NPL Net memiliki perhitungan yang sama dengan NPL Grossnamun NPL Net mengurangi PPAP (Penyisihan Penghapusan Aktiva Produktif) pada kredit bermasalah.

Penelitian menggunakan perhitungan NPL Gross yang memiliki proksi :

$\mathrm{NPL}=\frac{\text { Kredit Bermasalah }(3-5)}{\text { Total Kredit }} \boldsymbol{X} \mathbf{1 0 0} \%$

\section{Kerangka Teoritik}

Untuk menghubungkan CAR dengan kinerja keuangan yang diproksikan dengan pertumbuhan laba, maka kita dapat mengacu pada teori berikut ini.

Menurut Tim INDEF (Institute for Development of Economics and Finance) 
tahun 2003, CAR merupakan salah satu indikator yang berpengaruh terhadap kinerja keuangan perbankan. Ketentuan BI tentang CAR adalah sebesar $8 \%$ sehingga bagi bank-bank yang memiliki rasio CAR di bawah ketentuan mengindikasikan kinerja keuangan yang tidak baik.

Dikatakan oleh Henny, dkk (2011) bahwa jumlah modal merupakan dasar bagi kesehatan bank. Ditambahkan bahwa adanya pengembangan yang dilakukan oleh Basel Committee tentang standar kecukupan modal berbasis risiko bertujuan untuk memperkuat kesehatan sistem perbankan.

Menurut Hasibuan (2008) CAR merupakan indikator penilaian yang berpengaruh terhadap tingkat kesehatan. CAR 8\% di samping akan diperhitungkan dalam penilaian tingkat kesehatan bank, juga akan dikenakan sanksi dalam rangka pengawasan dan pembinaan bank.

Menurut Suta, dkk (2003) dalam upaya menyehatkan perbankan semestinya struktur permodalan bank mengacu pada standar internasional yang ditetapkan melalui Kesepakatan Modal Basel 1988 (Basel Capital Accord 1988). Dalam ketentuan itu bank diharuskan memelihara rasio kecukupan modalnya (CAR)di atas tingkat minimum $8 \%$.

Untuk menghubungkan NPL dengan kinerja keuangan yang diproksikan dengan pertumbuhan laba, maka kita dapat mengacu pada teori berikut ini.
Menurut Untung (2005) tentang kinerja bank dapat dikemukakan bahwa faktor-faktor yang mempengaruhi kinerja suatu bank menjadi buruk salah satunya adalah kredit macet yang tinggi.

Tim INDEF mengatakan dalam mengevaluasi kinerja bank digunakan beberapa indikator keuangan, salah satunya adalah indikator Non-Performing Loan (NPL).

Menurut Santoso, dkk (2005) adanya kredit macet akan mempengaruhi kinerja keuangan bank yang dinilai melalui tingkat kesehatan bank. Hal ini ditunjukkan dengan adanya rencana tindakan (action plan) untuk memperbaiki tingkat kesehatan bank salah satunya adalah dengan menangani kredit bermasalah (kurang lancar, diragukan, dan macet) secara intensif dan efektif.

Untuk menghubungkan CAR dan NPL dengan kinerja keuangan proksi pertumbuhan laba maka kita dapat mengacu pada teori berikut ini.

Menurut Tim INDEF salah satu tujuan bisnis yang tidak mungkin dihapuskan adalah menciptakan profit atau laba yang sebesar-besarnya. Dalam kaitan ini, untuk mengukur profitabilitas dari aktivitas bisnis perbankan dapat digunakan indikator yang disebut dengan NIM. Namun demikian perlu diperhatikan bahwa dalam mewujudkan profit tersebut tidak boleh dilupakan faktor lainnya yaitu seperti kapasitas lembaga (leverage power) yang ditunjukkan dengan indikator

Jurnal Ilmiah Wahana Akuntansi 
CAR, peluang untuk memperoleh keuntungan yang cukup besar ditunjukkan dengan indikator ROA, serta kemampuan mengelola risiko (risk management) yang ditunjukkan dengan indikator NPL.

Menurut Suta, dkk (2003) dalam program penyehatan perbankan selain memperhatikan struktur permodalan yang harus dimiliki suatu bank, juga dituntut untuk memperbaiki kelemahankelemahan, baik dalam hal pengelolaan risiko, sumber daya manusia, prosedur operasional, masalah kredit macet (nonperforming loan), dan pelaksanaan tata kelola yang baik.

Dikatakan oleh Yunika, dkk (2015). bahwa jika penilaian tingkat kesehatan bank buruk, maka diperlukan rencana tindakan (action plan) terhadap faktorfaktor yang mempengaruhinya antara lain dengan dengan menambah modal untuk bank yang memiliki CAR cenderung menurun, serta menangani kredit bermasalah (kurang lancar, diraguka, dan macet) secara intensif jika bank permasalahan seperti meningkatnya jumlah kredit bermasalah (kurang lancar, diragukan, dan macet).

\section{Rumusan Hipotesis}

Berdasarkan kerangka teoritik tersebut, dapat diajukan rumusan hipotesis sebagai berikut :

$\mathrm{H}_{1}$ : Terdapat pengaruh antara CAR (Capital Adequacy Ratio) dengan kinerja keuangan.

$\mathrm{H}_{2}$ : Terdapat pengaruh antara NPL (Non-Performing Loan) dengan kinerja keuangan.

$\mathrm{H}_{3}$ : Terdapat pengaruh antara CAR (Capital Adequacy Ratio) dan NPL (Non-Performing Loan) dengan kinerja keuangan.

\section{METODE PENELITIAN}

Data yang diperoleh melalui penelitian adalah data sekunder yang mempunyai kriteria tertentu yaitu:

a. Bank umum konvensional yang tercatat di Bank Indonesia dan masih aktif beroperasi pada periode 2012 - 2015.

b. Bank umum konvensional yang telah menerbitkan laporan tahunan 2015.

c. Bank umum konvensional yang tidak mengalami kerugian setiap tahunnya selama periode 2012 2015.

d. Bukan merupakan bank syariah ataupun memiliki unit usaha syariah.

e. Bukan merupakan data outlier, yang memiliki nilai ekstrim berbeda dari data yang lain.

Metode penelitian yang peneliti gunakan dalam penelitian ini adalah metode kuantitatif.

Pendekatan kuantitatif adalah penelitian yang analisisnya lebih fokus Jurnal IImiah Wahana Akuntansi 
pada data-data numerikal (angka) yang diolah dengan menggunakan metode statistika.

Dalam penelitian ini yang menjadi populasi adalah seluruh bank umum konvensional yang tercatat di Bank Indonesia. Berdasarkan kriteria yang dibuat, dari 114 populasi dan 43 populasi terjangkau, maka diperlukan 39 bank umum konvensional yang dijadikan sampel dalam penelitian ini setelah dieliminasi oleh data outlier.

\section{TEKNIK ANALISIS DATA}

\section{Statistik Deskriptif}

Analisis deskriptif adalah merupakan bentuk analisis data penelitian untuk menguji generalisasi hasil penelitian berdasarkan satu sampel.

\section{Uji Normalitas}

Pengujian terhadap normalitas data bertujuan untuk mengetahui distribusi data dalam variabel yang digunakan dalam penelitian.Dalam penelitian ini, uji normalitas yang digunakan adalah Kolmogorov-Smirnov.

\section{Pengujian Asumsi Klasik}

\section{Uji Multikolinearitas}

Pengujian multikolinearitas bertujuan untuk menguji keberadaan korelasi antar variabel independen dalam model regresi.Untuk mendeteksi ada tidaknya multikolinearitas dalam model regresi Jurnal Ilmiah Wahana Akuntansi dapat dilihat dari Tolerance Value atau Variance Inflation Factor (VIF).

\section{Uji Heterokedastisitas}

Untuk mendeteksi ada tidaknya heteroskedastisitas dapat dilakukan dengan melihat grafik scatterplot.Apabila terdapat pola tertentu, seperti titik-titik membentuk pola tertentu yang teratur, maka mengindikasikan bahwa telah terjadi heteroskedastisitas.

\section{Uji Autokorelasi}

Pengujian terhadap asumsi klasik autokorelasi bertujuan untuk mengetahui apakah terdapat korelasi antara kesalahan pengganggu pada data observasi satu pengamatan ke pengamatan lainnya dalam model regresi linear. Untuk mendeteksi ada atau tidaknya autokorelasi dapat dilakukan dengan pengujian DurbinWatson (DW).

\section{Uji Hipotesis}

Uji Regresi Linier Berganda

Pada penelitian ini, pengujian dilakukan dengan analisis regresi linear berganda, yaitu suatu metode statistik yang umum digunakan untuk menelitihubungan antara sebuah variabel dependen dengan beberapa variabel independen.

Adapun model regresi yang digunakan adalah:

\section{Pertumbu an Laba Bersi}

$$
=\alpha+\beta_{1} C A R+\beta_{2} N P L
$$




\section{Uji Simultan (Uji F)}

Uji simultan bertujuan untuk mengukur apakah semua variabel independen mempunyai pengaruh secara bersamasama terhadap variabel dependen.

\section{Uji Parsial (Uji t)}

Pengujian hipotesis untuk masingmasing variabel CAR dan NPL secara individu terhadap kinerja keuangan menggunakan ujisignifikansi individual.

\section{Koefisien Korelasi Ganda (Uji $R$ )}

Analisa ini digunakan untuk mengetahui hubungan antara dua atau lebih variabel independen terhadap variabel dependen secara serentak.

\section{Koefisien Determinasi $\left(R^{2}\right)$}

Analisis determinasi dalam regresi linear berganda digunakan untuk mengetahui persentase sumbangan pengaruh variabel independen terhadap variabel dependen secara serentak.

\section{HASIL PENELITIAN}

\section{Kinerja Keuangan}

Variabel kinerja keuangan dalam penelitian ini memiliki nilai minimum sebesar $-0,43$ yang merupakan pertumbuhan laba dari PT Bank DBS Indonesia. Nilai maksimum variabel kinerja keuangan yaitu sebesar 1,49\% yang merupakan pertumbuhan laba dari Jurnal IImiah Wahana Akuntansi
PT Bank National Nobu. Data kinerja keuangan dihitung dan menghasilkan nilai rata-rata sebesar 0,1967\%. Data yang dikumpulkan menghasilkan distribusi frekuensi data kinerja keuangan (proksi pertumbuhan laba) dimana rentang data adalah 1,92, kelas interval adalah 6 yang menggunakan rumus $\mathrm{K}=1+3,3 \log \mathrm{n}$, dan panjang kelas adalah 0,32.

Tabel 1

Distribusi Frekuensi Pertumbuhan Laba

\begin{tabular}{|c|c|c|c|c|c|}
\hline \multirow[b]{2}{*}{ se. } & \multirow[b]{2}{*}{ Tiliral } & & & \multicolumn{2}{|c|}{ Dillows: } \\
\hline & & $\begin{array}{l}\text { Rates } \\
\text { Tanxí }\end{array}$ & $\begin{array}{l}\text { Ears: } \\
\text { sass }\end{array}$ & Fesite1s & 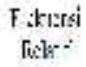 \\
\hline 1 & 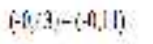 & -413 & $-(4) 1 \%$ & 5 & $13 x_{2}$ \\
\hline 2 & $1-i \mid 0$ & $\because 111$ & 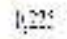 & 21 & $5 t^{x}$ \\
\hline 3 & $112 \quad 455$ & $\therefore 2:$ & 0.55 & : & $x x$ \\
\hline & 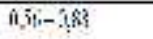 & 2.55 & 6835 & 1 & 14 \\
\hline 5 & $0,30 \quad], 21$ & $\therefore w !$ & $1.21:$ & $\underline{1}$ & 5 \\
\hline 6 & $1,2:-1,5$ & .15 & 1.24 & 1 & $1 \%$ \\
\hline \multicolumn{4}{|c|}{ Jumbh } & i) & tors \\
\hline
\end{tabular}

Sumber: Data diolah peneliti, 2016

Hasil distribusi data yang terdapat pada Tabel 1 menunjukkan bahwa frekuensi tertinggi yaitu $20(51 \%)$ yang terdapat pada batas nyata $(-0,10)-0,22$.

\section{Capital Adequacy Ratio(CAR)}

Variabel CAR dalam penelitian ini memiliki nilai minimum sebesar $13,42 \%$ yang merupakan CAR dari PT Bank Antardaerah. Nilai maksimum sebesar 78,16\% merupakan CAR dari PT Bank Multiarta Sentosa. Data CAR dihitung dan menghasilkan nilai rata-rata sebesar 27,4779. Data yang dikumpulkan menghasilkan distribusi frekuensi data CAR dimana rentang data adalah 64,73, 
kelas interval adalah 6, dan panjang kelas adalah 10,79 .

Tabel 2

Distribusi Frekuensi CAR

\begin{tabular}{|c|c|c|c|c|c|}
\hline & (Thalam \%) \\
\hline No. & Interval & Batas Bavah & Balas Alas & Frešivetsí & Fockactsi Relatuf \\
\hline 1 & $13,42-24,21$ & 13.415 & 24,215 & 25 & 645 \\
\hline 2 & $24,22-35,01$ & 24215 & 35,615 & 7 & $18 \%$ \\
\hline 3 & $3516-45,81$ & 35015 & 15,815 & 2 & 54. \\
\hline 1 & $15,82-56,61$ & 45815 & 56,515 & 0 & $0 s$ \\
\hline 5 & $56,62-67,41$ & 56,615 & 67415 & 1 & $3 x$ \\
\hline \multirow[t]{2}{*}{ b } & $67,42-7821$ & 67,415 & 78,215 & 4 & $10 \%$ \\
\hline & \multicolumn{3}{|c|}{ Jembh } & 19 & $10 \times h_{4}$ \\
\hline
\end{tabular}

Sumber: Data diolah peneliti, 2016

Hasil distribusi data yang terdapat pada Tabel 2menunjukkan bahwa frekuensi tertinggi yaitu 25 (64\%) yang terdapat pada batas nyata $13,42-24,21$. Sedangkan frekuensi terendah yaitu sebesar $0 \%$.

\section{Non-Performing Loan (NPL)}

Variabel NPL dalam penelitian ini memiliki nilai minimum sebesar $0,00 \%$ yang merupakan NPL dari 4 perusahaan perbankan, yaitu PT Bank National Nobu, PT Bank BNP Paribas Indonesia, Bank Of America, N.A., dan J.P. Morgan Chase Bank, NA. Sedangkan nilai NPL tertinggi atau nilai maksimum adalah 3,10\% merupakan NPL dari Bank Pembangunan Daerah (BPD) Papua. Data NPL dihitung dan menghasilkan nilai rata-rata sebesar 1,0262. Data yang dikumpulkan menghasilkan distribusi frekuensi data NPL dimana rentang data adalah 3,10, kelas interval adalah 6 , dan panjang kelas adalah 0,52 .

Jurnal IImiah Wahana Akuntansi
Tabel 3

Distribusi Frekuensi NPL

(Dalam \%)

\begin{tabular}{|c|c|c|c|c|c|}
\hline No. & Trterval & Batas Bawah & Batas Anss & Frekuensi & Frekuensi Relarif \\
\hline 1 & $0,00-0,52$ & $-0,005$ & 0,525 & 16 & $41 \%$ \\
\hline 2. & $0,53-1,05$ & 0,525 & 1,055 & 6 & $15 \%$ \\
\hline 3. & $1,06-1,58$ & 1,055 & 1,585 & 8 & $21 \%$ \\
\hline 4. & $1,59-2,11$ & 1,585 & 2115 & 3 & $8 \%$ \\
\hline 5. & $2,12-2,64$ & 2,115 & 2,645 & 4 & $10 \%$ \\
\hline 6. & $2,65-3,17$ & 2,645 & 3,175 & 2 & $5 \%$ \\
\hline & \multicolumn{3}{|c|}{ Jumlah } & 39 & $100 \%$ \\
\hline
\end{tabular}

Sumber: Data diolah peneliti, 2016

Hasil distribusi data yang terdapat pada Tabel 3menunjukkan bahwa frekuensi tertinggi yaitu 16 (41\%) yang terdapat pada batas nyata $0,00-0,52$. Sedangkan frekuensi terendah yaitu sebesar $5 \%$.

Berdasarkan hasil SPSS dari hasil One-sample Kolmogorov-Smirnov Test, nilai uji normalitas dihitung dengan menggunakan nilai residu. Setelah dilakukan perhitungan, maka didapat nilai uji normalitas sebesar 0,419>0,05 maka dapat dikatakan bahwa data berdistribusi normal.

Uji multikolinearitas menunjukkan bahwa masing-masing variabel memiliki nilai VIF CAR dan NPL 1,080 (VIF<10) untuk semua variabel independen dan nilai tolerance untuk semua variabel independen sebesar 0,926>0,10 sehingga tidak ada persoalan multikolinearitas diantara variabel-variabel independen.

Uji Heterokedastisitas yang terdapat pada Gambar 1, Scatterplot tidak memperlihatkan sebuah pola tertentu, dan titik-titik menyebar di atas dan di bawah angka 0 pada sumbu Y. Hal ini 
menunjukkan bahwa model regresi bebas dari heteroskedastisitas.

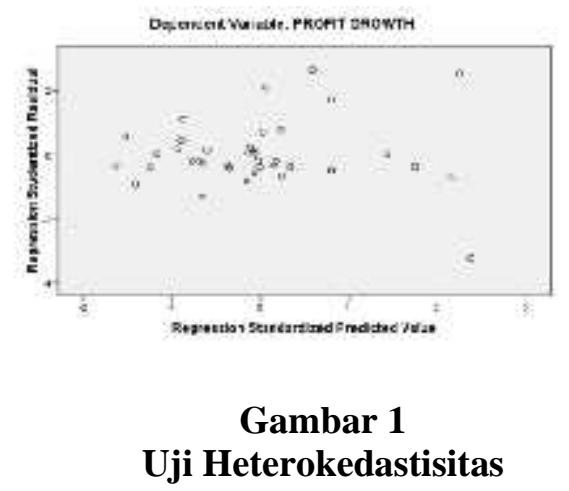

Sumber: Data diolah peneliti, 2016

Uji Autokorelasi, diketahui DW = 1,772, dU $=1,596$. Data dalam penelitian ini menyatakan DW terletak diantara dU dan (4-dU) yaitu 1.596<1.772<2.404.maka data tersebut bebas dari autokorelasi.

Hasil analisis regresi antara CAR dengan kinerja keuangandan NPL dengan kinerja keuangan terdapat pada Tabel 4.Model regresi yang dihasilkan pada penelitian ini adalah sebagai berikut:

Kinerja Keuangan $($ Pertumbuhan Laba $)=$

$$
0,061+0,010(\mathrm{CAR})-0,133(\mathrm{NPL})
$$

\section{Tabel 4}

Uji Parsial (Uji t)

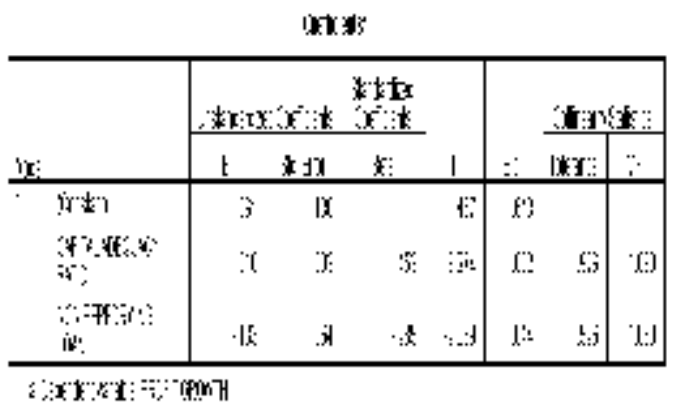

Sumber: Data diolah peneliti, 2016

Jurnal IImiah Wahana Akuntansi
Nilai koefisien konstanta $=0,061$. Artinya, apabila nilai CAR dan NonPerforming Loan pada objek penelitian sama dengan nol maka besarnya variabel dependen pertumbuhan laba sebesar 0,061.

Nilai koefisien $b_{1}=0,010$. Artinya, jika nilai CAR mengalami kenaikan sebesar 1 satuan, sementara variabel lain bersifat tetap maka tingkat variabel Pertumbuhan Laba akan meningkat sebesar 0,010 kali.

Nilai koefisien $b_{2}=-0,133$. Artinya, jika nilai Non Performing Loan mengalami kenaikan sebesar 1 satuan maka jumlah variabel Pertumbuhan Laba akan menurun sebesar 0,133 kali.

$$
F_{\text {hitung }}>\quad F_{\text {tabelyaitu }} \text { 10,152> 3,26, }
$$

maka $\mathrm{H}_{0}$ ditolak. Nilai signifikan yaitu $0.000<0.05$. Jadi dari hasil ini dapat disimpulkan bahwa CAR dan NPL berpengaruh positif dan signifikan terhadap kinerja keuangan (pertumbuhan laba).

Tabel 5

\begin{tabular}{|c|c|c|c|c|c|c|}
\hline \multicolumn{7}{|c|}{ N.IWh' } \\
\hline 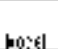 & & 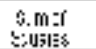 & $\therefore$ & 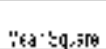 & r & 3. \\
\hline 1 & $. e x:=\$ 30^{\prime}$ & $\bar{r} \cdot \overline{\mathrm{s}}$ & $?$ & $1 \%$ & $\Gamma^{-15}$ & $\mathrm{in}^{\circ}$ \\
\hline & ا..lו :ור & $\cdots 3$ & ili & $x$ & & \\
\hline & mil & $\because \% 8$ & 38 & & & \\
\hline
\end{tabular}
Uji Simultan (Uji F)

Sumber: Data diolah peneliti, 2016

Tingkat signifikansi CAR adalah 0,002 yang berarti $<0,05(5 \%)$ dan $\mathrm{t}$ hitung 3,274 maka 3,274>2,028 menunjukkan bahwa $\mathrm{H}_{0}$ ditolak sehingga dapat disimpulkan bahwa variabel CAR 
berpengaruh positif dan signifikan terhadap Pertumbuhan Laba.

Tingkat signifikansi NPL adalah 0,044 yang berarti $<0,05(5 \%)$ dan $t_{\text {hitung }^{-}}$ 2,089 maka 2,089 > 2,028 menunjukkan bahwa $\mathrm{H}_{0}$ ditolak sehingga dapat disimpulkan bahwa variabel NPL berpengaruh negatif dan signifikan terhadap Pertumbuhan Laba.

Hasil uji Rdan hasil dari koefisien determinasi dinyatakan bahwa $\mathrm{R}^{2}$ adalah:

Tabel 6

$\mathrm{Uji} \mathbf{R}^{2}$

Model Suniritran'

\begin{tabular}{|c|c|c|c|c|c|}
\hline $\mathrm{L}^{k}$ & $?$ & Ri: Jare & 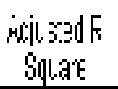 & 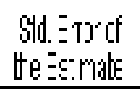 & 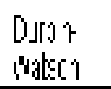 \\
\hline 1 & $30^{\prime}$ & $F^{\circ}$ & $3 \mathrm{kE}$ & $3300 ?$ & 77 \\
\hline
\end{tabular}

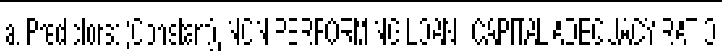

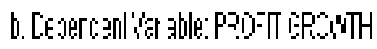

Sumber: Data diolah peneliti, 2016

\section{PEMBAHASAN}

Di dalam penelitian ini menunjukkan bahwa terdapat hubungan pengaruh yang positif dan signifikan antara CAR dengan Pertumbuhan Laba. Artinya, semakin besar CAR yang dimiliki oleh bank, maka semakin besar pula pergerakan pertumbuhan laba bank tersebut.

CAR mempengaruhi pertumbuhan laba secara positif disebabkan oleh kedua variabel tersebut termasuk ke dalam komponen penting dalam dunia perbankan. Selain menyalurkan kredit dan memberikan jasa dalam lalu lintas Jurnal IImiah Wahana Akuntansi pembayaran, bank dalam kegiatan utamanya juga mencari keuntungan. Dalam setiap pelaksanaan kegiatan, bank termasuk ke dalam perusahaan yang membutuhkan modal.

CAR merupakan rasio keuangan yang berkaitan dengan permodalan perbankan dimana besarnya modal suatu bank akan berpengaruh pada mampu atau tidaknya suatu bank secara efisien menjalankan kegiatan usahanya untuk selanjutnya menghasilkan keuntungan berupa laba.

Dengan adanya ketentuan besarnya modal minimum yang wajib dimiliki oleh bank, menandakan bahwa bank tersebut diperkirakan dapat beroperasi dengan baik karena sudah memenuhi ketentuan yang ditetapkan serta modal tersebut dapat digunakan untuk mengantisipasi timbulnya kerugian-kerugian akibat risiko kredit, pasar, maupun operasional. Kemudian jika bank sudah memenuhi CAR di atas ketentuan, bank sudah dapat menjalankan kegiatan usahanya dan memaksimalkan keuntungan yang didapat. Keuntungan yang didapat akan mempengaruhi pergerakan pertumbuhan laba setiap tahunnya.

Hasil penelitian ini sejalan dengan penelitian sebelumnya yang menjadi bahan referensi bagi peneliti, yaitu penelitian yang dikemukakan oleh Syahputra, Andreas, dan Wijaya (2014); Hidayatullah dan Febrianto (2012); serta Anisah Lubis (2013). Dimana hasil penelitian terdahulu tersebut juga 
menjelaskan bahwa CAR berpengaruh positif dan signifikan terhadap pertumbuhan laba.

Berdasarkan nilai koefisien CAR pada model regresi ganda yang bernilai 0,010 maka dapat disimpulkan bahwa jika CAR bertambah dengan kenaikan setiap $1 \%$ maka persentase pertumbuhan laba akan bertambah $0,010 \%$.

Pada penelitian ini menunjukkan bahwa terdapat hubungan pengaruh yang negatif dan signifikan antara Non Performing Loan dengan pertumbuhan laba. Artinya, jika nilai Non Performing Loan dari suatu bank semakin besar maka semakin kecil pertumbuhan laba bank tersebut. Begitupun sebaliknya, jika nilai Non Performing Loan suatu bank semakin kecil, maka semakin besar pertumbuhan laba bank tersebut.

Non Performing Loan mempengaruhi pertumbuhan laba secara negatif dikarenakan Non Performing Loan membuat bank mengalami kerugian. Pendapatan bunga yang seharusnya diterima dan menjadi laba bagi bank, tidak mampu diberikan oleh nasabah. Bahkan, pinjaman yang sudah diberikan oleh bank tidak mampu dikembalikan oleh nasabah. Akibatnya, laba yang diterima oleh bank akan semakin kecil bahkan terancam mengalami kerugian karena bank turut menanggung serta nilai kredit yang sudah diberikan. Maka dapat ditarik kesimpulan, jika semakin tinggi nilai Non Performing

Jurnal Ilmiah Wahana Akuntansi
Loan, pertumbuhan laba akan semakin menurun.

Hasil peneli

\section{KESIMPULAN DAN SARAN}

\section{Kesimpulan}

Berdasarkan analisis yang telah lakukan, maka dapat disimpulkan bahwa:

1. CAR memiliki pengaruh positif dan signifikan terhadap persentase pertumbuhan laba.

2. Non Performing Loan memiliki pengaruh negatif dan signifikan terhadap persentase pertumbuhan laba.

3. CAR dan Non Performing Loan secara bersama-sama berpengaruh positif dan signifikan terhadap pertumbuhan laba.

\section{Implikasi}

1. CAR berpengaruh positif dan signifikan terhadap persentase pertumbuhan laba. Dapat diartikan bahwa besar kecilnya persentase pertumbuhan laba dipengaruhi oleh CAR yang berkaitan dengan rasio permodalan minimum yang harus dimiliki oleh suatu bank dalam menjalankan kegiatan usahanya secara efisien.

2. Non Performing Loan memiliki pengaruh negatif dan signifikan terhadap persentase pertumbuhan laba. Dapat diartikan bahwa besar kecilnya Non Performing Loan akan mempengaruhi besar kecilnya 
persentase pertumbuhan laba karena nilai Non Performing Loan dapat menggambarkan seberapa besar pinjaman para nasabah yang tidak dapat dikembalikan beserta bunga yang menjadi sumber utama pendapatan bank sehingga mempengaruhi persentase penerimaan laba.

3. Bagi investor, penelitian ini berimplikasi pada keputusan investasi yang akan dilakukan. Penelitian ini memberikan informasi kepada investor tentang sejauh mana perusahaan perbankan mampu memberikan keuntungan dalam kurun waktu 3 tahun terakhir.

4. Bagi pihak bank, penelitian ini berimplikasi pada reputasi bank yang memiliki kinerja keuangan yang baik. Artinya bank berada pada tingkat kesehatan yang baik.

\section{Saran}

\section{Bagi Pihak Bank}

1. Bank harus menjaga rasio permodalan agar berada pada posisi yang baik dan di atas $14 \%$ dengan cara menjaga kelancaran sistem pembayaran. Karena rasio permodalan yang baik akan berpengaruh pada kemampuan bank dalam menjalankan kegiatan usahanya secara efisien sehingga dapat menghasilkan laba.

2. Bank juga harus lebih selektif dalam memberikan kredit dengan menerapkan 5C (Capital, Collateral, Characteristic, Condition of Economic, Capability) dan melaksanakan analisis kredit dengan tepat agar bank terhindar dari kerugian yang ditimbulkan akibat ketidakmampuan nasabah dalam membayar pinjaman beserta bunga yang dikenal dengan istilah kredit macet atau Non Performing Loan (NPL). Rasio NPL yang dimiliki oleh bank hendaknya tetap stabil atau menurun sesuai batas yang telah ditentukan yaitu sebesar $5 \%$.

\section{Bagi Investor}

1. Keputusan untuk berinvestasi pada suatu perusahaan perbankan, sangat ditentukan dari bagaimana kemampuan bank tersebut dalam menghasilkan laba dan kestabilan usaha. Untuk itu perlu dicermati faktor-faktor apa saja yang mempengaruhi persentase pertumbuhan laba perbankan selama rata-rata tiga tahun terakhir. Faktorfaktor yang mempengaruhi pertumbuhan laba tersebut contohnya dapat dilihat dari rasio permodalan atau Capital Adequacy Ratio serta besarnya nilai kredit macet suatu bank atau Non Performing Loan yang sudah dijelaskan dalam penelitian ini. Selain itu, adanya faktor makro berupa kondisi perekonomian yang sedang memburuk pada periode 2013 
- 2015 hendaknya juga menjadi

bahan pertimbangan bagi investor

dalam melakukan kegiatan investasi

pada perusahaan perbankan 


\section{DAFTAR PUSTAKA}

Anisah Lubis. "Pengaruh Tingkat Kesehatan Bank Terhadap Pertumbuhan Laba Pada BPR Di Indonesia". Jurnal Ekonomi dan Keuangan. Volume 1, No. 4, Februari 2013.

Arthesa, Ade. 2009. Bank dan Lembaga Keuangan Bukan Bank. Jakarta: PT Indeks.

Greuning, Henny van, dkk. 2011. Analisis Risiko Perbankan. Jakarta: Salemba Empat.

Hasibuan, Malayu. 2008. Op. Cit.

Hidayatullah dan Roby Febriant. "Analisis Pengaruh Rasio CAMELS Terhadap Pertumbuhan Laba Pada Perusahaan Perbankan Yang Terdaftar Di Bursa Efek Indonesia”. Jurnal Akuntansi, Fakultas Ekonomi dan Bisnis Universitas Bina Nusantara. Volume 3 No. 2, November 2012, ISSN: 614-632.

Murdayanti, Yunika dkk. 2015. Bank dan Lembaga Keuangan Lainnya. Jakarta: LPP FE UNJ.

Renaldy Syahputra, Andreas, Errin Yani Wijaya. "Pengaruh Rasio Keuangan Terhadap Pertumbuhan Laba Bank Pembangunan Daerah Di Indonesia Dengan Pertumbuhan Kredit Sebagai Variabel Intervening". Jurnal Tepak Manajemen Bisnis.Volume VI No. 2, Mei 2014.

Riyadi, Slamet. 2004. Op.Cit.

Santoso, Totok Bud, dkk. 2011. Bank dan Lembaga Keuangan Lain. Jakarta: Salemba Empat.

Suta, I Putu Gede Ary, dkk. 2003. Membedah Krisis Perbankan (Anatomi Krisis dan Penyehatan Perbankan). Jakarta: Yayasan SAD SATRIA BHAKTI.

Timothy. MacDonald. 2003 Bank Management. U.S. America: SouthWestern.

Jurnal IImiah Wahana Akuntansi
Tim INDEF. 2003. Restrukturisasi Perbankan di Indonesia. Jakarta: Perpustakaan Nasional.

Untung, Budi. 2005. Kredit Perbankan di Indonesia. Andi: Yogyakarta 